\title{
KEBIJAKAN PEMILIHAN BAHASA PADA LINGKUP KELUARGA DAN MASYARAKAT DI RUANG PUBLIK
}

\section{LANGUAGE SELECTION POLICIES IN THE SCOPE OF FAMILY AND SOCIETY IN PUBLIC SPACE}

\author{
Abdul Haliq ${ }^{a, *}$, Widyawati Palupi ${ }^{\mathrm{b}, *}$, Sri Wahyu Widiatic,"* \\ ${ }^{a}$ Universitas Negeri Makassar \\ Pos-el: abdul.haliq@unm.ac.id \\ Diterima: 07 November 2018; Direvisi: 05 Desember 2018; Disetujui: 31 Desember 2018
}

\begin{abstract}
This study aims to find out two things, namely, (1) factors that influence the family to determine language selection policies and (2) factors that influence society in the use of language in the public space. This study took samples in several regions including, Magelang, Wonogiri, Yogyakarta, Makassar, and Tanjung Pinang. The type of research used is qualitative. Data collection techniques are carried out by observation and interviews. The collected data is then analyzed using descriptive qualitative techniques. The results of data analysis show that (1) the choice of language used in the family scope is influenced by factors, namely the first language of the family member, the language used in the neighborhood, the language of education and the media; (2) The policy of language selection in public space is influenced by several factors, namely the purpose of using language, institutional policy or local government, and the rules for using the language stated in Law No. 28 of 2009. (3) The use of language in the public sphere which generally uses mixed code between Indonesian and regional / foreign languages has the purpose and objectives adjusted to its designation. (4) The use of foreign / English languages in public spaces still violates many government regulations that have been invited.
\end{abstract}

Key word: policy, language, family, selection, public.

\begin{abstract}
Abstrak
Penelitian ini bertujuan mengetahui dua hal yaitu, (1) faktor-faktor yang memengaruhi keluarga menentukan kebijakan pemilihan bahasa dan (2) faktor-faktor yang memengaruhi masyarakat dalam penggunaan bahasa di ruang publik.Penelitian ini mengambil sampel di beberapa wilayah di antaranya, Magelang, Wonogiri, Yogyakarta, Makassar, dan Tanjung Pinang.Jenis penelitian yang digunakan yaitu kualitatif. Teknik pengumpulan data dilakukan dengan cara observasi dan wawancara. Data yang telah terkumpul selanjutnya dianalisis menggunakan teknik kualitatif deskriptif.Hasil analisis datamenunjukkan bahwa (1) pemilihan bahasa yang digunakan dalam ruang lingkup keluarga dipengaruhi oleh faktor-faktor yaitu bahasa pertama anggota keluarga, bahasa yang digunakan di lingkungan tempat tinggal, bahasa pendidikan dan media; (2) Kebijakan pemilihan bahasa di ruang publik dipengaruhi oleh beberapa faktor yaitu tujuan penggunaan bahasa, kebijakan institusi atau pemerintah daerah, dan aturan penggunaan bahasa yang tertera pada Undang-Undang No. 28 tahun 2009. (3) Penggunaan bahasa di ranah publik yang umumnya menggunakan campur kode antara bahasa Indonesia dengan bahasa daerah/asing memiliki maksud dan tujuan yang disesuaikan dengan peruntukannya. (4) Penggunaan bahasa asing/Inggris di ruang publik masih banyak melanggar peraturan pemerintah yang telah diundang-undangkan.
\end{abstract}

Kata kunci: kebijakan, bahasa, pemilihan, keluarga, publik. 


\section{PENDAHULUAN}

Bahasa sebagai media komunikasi merupakan hal yang sangat krusial bagi manusia sebagai makhluk sosial. Keberadaan bahasa mengakibatkan manusia yang hidup berkelompok (masyarakat) dapat saling berkomunikasi ataupun mengekspresikan diri baik melalui bahasa lisan maupun bahasa tulis. Bahasa hadir sebagai kebutuhan dasar masyarakat untuk saling berinteraksi.

Penggunaan bahasa sebagai media komunikasi sangat erat kaitannya dengan pemilihan bahasa. Hal ini sangat mungkin terjadi di tengah-tengah masyarakat yang multibahasawan, khususnya untuk konteks keIndonesia-an, hampir semua masyarakatnya multibahasawan.Fenomena ini terjadi dikarenakan keberadaan ragam bahasa daerah sebanyak 726 (Paul, 2009) yang berasal dari suku bangsa yang berbeda-beda dan ditambah dengan kehadiran bahasa Indonesia sebagai lingua franca bagi masyarakat yang berbeda bahasa daerah mengakibatkan masyarakat sangat membutuhkan penguasaan bahasa yang lebih dari satu bahasa saja. Kemultibahasaan merupakan kebutuhan masyarakat Indonesia sebagai sarana

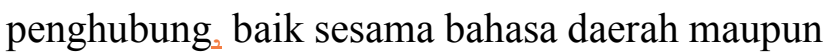
berbeda bahasa daerah.

Kebijakan penggunaan bahasa adalah hal yang mutlak terjadi ${ }_{2}$ baik dalam lingkungan keluarga maupun masyarakat. Kebijakan pemilihan bahasa di lingkup keluarga tentunya ditentukan oleh keluarga itu sendiri. Di lingkup kebijakan bahasa untuk masyarakat diatur melalui peraturan-peraturan yang dikeluarkan oleh instansi terkait seperti pemerintah pusat, daerah, kementrian, ataupun badan bahasa yang memang berurusan dengan pengembangan bahasa khususnya bahasa Indonesia. Kebijakan bahasa dilakukan oleh pemerintah dalam rangka pemertahanan bahasa daerah ataupun untuk menguatkan jati diri bangsa yang berupa identitas yakni bahasa Indonesia.

Penelitian ini dilakukan untuk mengkaji faktor-faktor yang memengaruhi kebijakan bahasa dan juga dampak dari kebijakan bahasa tersebut $_{2}$ baik dalam lingkungan keluarga mupun di lingkungan masyarakat. Pemilihan lokasi penelitian berasal dari beberapa daerah yang disesuaikan domisili peneliti untuk melihat sebaran kebijakan-kebijakan bahasa yang dilakukan baik dalam keluarga maupun oleh pemerintah secara umum.

\section{LANDASAN TEORI}

\section{Kebijakan Pemilihan bahasa}

Merunut pada rumusan yang disepakati dalam seminar politik bahasa nasional yang diadakan di Jakarta tahun 1975, kebijakan bahasa diartikan sebagai pertimbangan konseptual dan politis yang dimaksudkan untuk dapat memberi perencanaan, pengarahan dan ketentuanketentuan yang dapat dipakai sebagai dasar bagi pengelolaan keseluruhan kebahasaan yang dihadapi oleh suatu bangsa secara nasional. Kebijakan bahasa (language policy) sering mengacu pada tujuan yang menyangkut bahasa, 
politik, dan masyarakat yang mendasari usaha kegiatan para perencana bahasa (Cooper, 1989).

Pemilihanbahasa umumnya terjadi pada ruang-ruang yang masyarakatnya merupakan multibahasa. Masyarakat yang multibahasa terjadi akibat adanya kontak bahasa, sosial, dan budaya dengan mayarakat lain yang berbeda. Seperti yang dikemukakan oleh Fasold (1984) timbulnya pemilihan bahasa terjadi akibat adanya kontak bahasa, sosial, dan budaya sehingga memunculkan masyarakat tutur yang memiliki kemampuan untuk memilih bahasa atau kode bahasa dalam peristiwa tertentu, baik mempertahankan bahasa pertama maupun melakukan pergeseran bahasa ke bahasa baru atau mencampurkan bahasa pertama dengan bahasa baru. Pada konteks Indonesia yang memiliki banyak bahasa daerah dan satu bahasa persatuan memunculkan masyarakat yang mampu menggunakan bahasa lebih dari satu (multibahasa). Hal ini dapat terjadi pada lingkungan keluarga baik yang berasal dari suku bangsa yang berbeda secara bahasa maupun berasal dari suku bangsa yang sama. Adanya bahasa Indonesia sebagai bahasa persatuan dan digunakan sebagai lingua franca dalam konteks Indonesia mengakibatkan penguasaan terhadap bahasa Indonesia menjadi wajib hukumnya.

Penggunaan dan pemilihan bahasa juga terjadi di ruang publik. Meski telah diaturdalam Undang-Undang No. 24 tahun 2009 khususnya tentang bahasa, namun pada praktiknya penggunaan bahasa di ruang publik cenderung tidak mengikuti peraturan tersebut. Penggunaan dan pemilihan bahasa disesuaikan dengan kebutuhan pengguna bahasa, sehingga kontak antarbahasa seringkali terjadi di ruang publik.

\section{METODE PENELITIAN}

Jenis penelitian yang digunakan dalam penelitian ini yaitu kualitatif. Instrumen penelitian ini yaitu peneliti sendiri. Peneliti bertindak sebagai instrumen kunci untuk memastikan data yang diperoleh apakah data tersebut telah memenuhi kebutuhan penelitian. Teknik pengumpulan data menggunakan dokumentasi dan wawancara secara tidak terstruktur antara peneliti dan responden. Teknik wawancara terhadap responden dilakukan untuk mengetahui faktor kebijakan pemilihan bahasa dalam ranah keluarga. Sementara itu, teknik dokumentasi digunakan untuk memperoleh data penggunaan bahasa di ruang publik. Dalam penelitian ini, penulis mengambil data di beberapa lokasi yaitu Magelang, Yogyakarta, Makassar, Tanjung Pinang, dan Wonogiri. Penentuan jumlah sampel disesuaikan dengan kebutuhan peneliti, dan apabila data yang telah ditemukan cenderung sama, maka penelitian dihentikan. Pemilihan sampel yang dilakukan berdasarkan beberapa kriteria yang telah ditetapkan peneliti, di antaranya keluarga yang berasal dari satu suku, keluarga yang berasal dari suku yang berbeda (nikah campur), keluarga yang berasal dari satu suku namun tinggal di lingkungan yang berbeda dengan suku aslinya, dan keluarga yang berasal dari satu suku yang 
berbeda dan menetap pada lingkungan salah satu suku anggota keluarga.

Begitu pula dengan data terkait penggunaan bahasa di ruang publik juga diperoleh dari kelima daerah tersebut. Data yang terkumpul selanjutnya dianalisis dengan menggunakan teknik kualitatif deskriptif berdasarkan model analisis Miles \& Huberman. Analisis data ini dilakukan secara interaktif melalui proses reduksi data, datadisplay, dan verifikasi data.

\section{PEMBAHASAN}

Berdasarkan data yang dikumpulkan dan hasil analisis menunjukkan bahwa pemilihan atau kebijakan bahasa baik dalam lingkup keluarga maupun dalam ruang publik memerhatikan beberapa faktor.Kebijakan bahasa di lingkup keluarga dipengaruhi oleh bahasa pertama anggota keluarga, bahasa di lingkuangan tempat tinggal, dan bahasa pendidikan dan media.Penggunaan bahasa di ruang publik dipengaruhi olehfaktor tujuan, dan kebijakan institusi, dan aturan kebahasaan yang ditetapkan oleh pemerintahdalam Undang-Undang No. 28 tahun 2009.

\section{Kebijakan Pemilihan Bahasa di Lingkup Keluarga}

Berdasar dari hasil penelitian yang dilakukan, terdapat beberapa faktor yang mendasari orang tua atau keluarga dalam mengambil kebijakan pemilihan bahasa yang digunakan dalam keluarga di antaranya:

\section{Bahasa Pertama Anggota Keluarga}

Dalam menentukan kebijakan pemilihan bahasa dalam lingkup keluarga biasanya memerhatikan bahasa pertama atau bahasa daerah dari anggota keluarga. Apabila anggota keluarga (suami dan istri) berasal dari bahasa daerah yang sama, kecenderungan untuk memilih menggunakan bahasa daerah dalam ranah keluarga lebih tinggi, sementara bagi keluarga (suami dan istri) yang berasal dari bahasa daerah yang berbeda, kecenderungan untuk memilih menggunakan bahasa Indonesia dalam ranah keluarga lebih tinggi.

2. Bahasa yang Digunakan di Lingkungan Tempat Tinggal

Bahasa yang digunakan oleh lingkungan kerap kali memengaruhi kebijakan pemilihan bahasa dalam rumah tangga. Dari beberapa responden yang kami wawancarai, pemilihan bahasa juga sangat ditentukan oleh bahasa di lingkungan tempat tinggal. Bagi kalangan perantau yang masih sama-sama berasal dari satu bahasa daerah, komunikasi suami istri cenderung masih menggunakan bahasa daerah.Namun demikian bahasa yang diajarkan kepada anak sudah bukan bahasa daerah lagi, melainkan bahasa Indonesia. Hal ini dilakukan untuk memudahkan anak dalam bersosialisasi di lingkungan. Lain halnya dengan keluarga yang berasal dari bahasa daerah yang berbeda dan tinggal di lingkungan yang salah satu anggota keluarga 
menggunakan bahasa daerah sesuai dengan lingkungan. Bahasa yang digunakan untuk komunikasi keluarga cenderung lebih memilih bahasa Indonesia. Namun, jika Ibu yang berasal dari bahasa daerah yang sama dengan lingkungan maka ibu cenderung mengajarkan anaknya bahasa daerah, sedangkan untuk komunikasi dengan bapak menggunakan bahasa Indonesia. Berbeda halnya jika seorang suami yang berbahasa daerah yang sama dengan bahasa daerah yang digunakan dalam lingkungan sendiri, apabila berkomunikasi dengan istri bahasa yang digunakan adalah bahasa Indonesia. Akan tetapi, anak dari keluarga tersebut tetap menggunakan bahasa daerah meskipun ibu mereka mengajarkan bahasa Indonesia kepada anak-anak mereka. Dalam kasus ini, bahasa daerah cenderung diperoleh dari lingkungan setempat dan bahasa ibu digunakan sebagai bahasa kedua.

\section{Bahasa Pendidikan dan Media}

Setakat ini, pemilihan bahasa Indonesia sebagai bahasa pertama yang diajarkan kepada anak sudah sangat lazim digunakan. Sebagian besar responden yang peneliti wawancarai memilih bahasa Indonesia sebagai bahasa yang diajarkan kepada anak. Hal ini disebabkan olehbahasa Indonesia sudah sangat familiar dan digunakan oleh hampir seluruh masyrakat Indonesia. Selain itu, mengajarkan bahasa kepada anak sama dengan mempersiapkan anak untuk menghadapi pendidikan. Bahasa yang digunakan dalam dunia pendidikan adalah bahasa Indonesia.

Hal yang lain yang menjadi alasan orang tua dalam mengajarkan bahasa Indonesia dikarenakan media-media yang dapat digunakan untuk melatih anak berbicara umumnya menggunakan bahasa Indonesia. Misalnya pengenalan warna, nama buah, nama hewan dan lain sebagainya melalui video-video yang menggunakan bahasa Indonesia. Selain itu, tontonan media televisi dan bahan bacaan juga umumnya menggunakan bahasa Indonesia, sehingga anak lebih dini dipersiapkan untuk mengenali bunyi dan tulisan dalam bahasa Indonesia.

\section{Kebijakan Pemilihan Bahasa di Ruang Publik}

Pemakaian bahasa dalam ranah publik menjadi wewenang pemerintah untuk mengeluarkan peraturan, baik itu pemerintah daerah maupun pemerintah pusat. Kebijakan bahasa oleh pemerintah pusat telah dilakukan dengan cara membuat peraturan tentang bahasa. Salah satunya yang tertuang dalam UndangUndang No. 24 tahun 2009 tentang Bendera, Bahasa, Lambang Negara, dan Lagu Kebangsaan. Ada juga yang terdapat dalam pasal 36 tentang bahasa negara. Selain itu, salah satu bentuk perhatian pemerintah terhadap bahasa yaitu adanya badan yang dibuat secara khusus untuk mengurus bahasa, yakni Badan Bahasa yang wilayah pekerjaannya terkait dengan pengembangan bahasa nasional (bahasa Indonesia) dan bahasa daerah. Salah satu slogan 
yang sangat akrab bagi akademisi khususnya di bidang bahasa yakni "utamakan bahasa Indonesia, lestarikan bahasa daerah, dan kuasai bahasa asing" tidaklah merupakan slogan semata.Namun sekiranya dapat diaplikasikan dalam bentuk tindakan dalam kehidupan berbangsa dan bernegara.

Senada dengan itu, Kurikulum pendidikan juga telah mengakomodasi pengajaran bahasa untuk dimasukkan ke dalam konten lokal. Konten lokal ini disesuaikan dengan unsur kebudayaan masing-masing daerah. Beberapa pemerintah daerah telah mengeluarkan peraturan terkait dengan memasukkan mata pelajaran bahasa daerah ke dalam kurikulum.Namun demikian beberapa daerah juga belum memiliki kebijakan tersebut. Kebijakan bahasa pada dasarnya digunakan sebagai langkah politik pemerintah untuk mempertahankan penggunaan suatu bahasa, baik bahasa nasional maupun bahasa daerah. Mempertahankan bahasa daerah sama dengan mempertahankan kekayaan kebudayaan daerah Indoneisa.

Penggunaan bahasa di ranah publik kadang kala masih menggunakan campur kode antara bahasa Inggris dan bahasa Indonesia ataupun menggunakan bahasa Inggris sepenuhnya. Meskipun dalam Undang-Undang No. 24 tahun 2009pasal 38 dan pasal 39 tentang penggunaan bahasa daerah dan asing dalam publikasi telah diatur sedemikian rupa.Namun penggunaan bahasa di ruang publik masih cenderung mana suka. Kecenderungan ini terjadi pada saat pemilihan bahasa asing dalam beberapa publikasi komersial dilakukan untuk memilah produk ataupun jasa yang sudah memiliki kelas tinggi dan setara dengan produk atau jasa yang ditawarkan di dunia internasional. Penggunaan bahasa Inggris juga tidak lepas dari kedudukan bahasa Inggris sebagai bahasa penghubung dunia internasional. Bahasa Inggris dijadikan sebagai penanda suatu program ataupun institusi yang memiliki program ataupun fasilitas yang bertaraf internasional.

Berdasarkan data yang dikumpulkan oleh peneliti di beberapa daerah, berikut dipaparkan hasil yang diperoleh terkait dengan penggunaan bahasa dalam ranah publik.

\section{Iklan pada Spanduk dan Baliho}

Pada iklan yang ditemukan di beberapa lokasi, setidaknya terdapat dua jenis, yaitu iklan komersial dan iklan sosialisasi kegiatan. Pola penggunaan bahasanyapun bervariasi, yaitu penggunaan bahasa Indonesia, penggunaan bahasa asing (Inggris), penggunaan campur kode bahasa Indonesia dan bahasa asing (Inggris), serta penggunaan bahasa daerah.

Penggunaan bahasa Indonesia dalam iklan ditemukan di Yogyakarta pada iklan sebuah rumah sakit bertaraf internasional yang bertuliskan "telah hadir untuk melayani Anda, Rumah Sakit Siloam Yogyakarta". Pemilihan bahasa Indonesia sebagai bahasa iklan pada baliho yang terpajang di jalan merupakan salah satu strategi dalam rangka pendekatan kepada setiap lapisan masyarakat sebagai bentuk perkenalan rumah sakit. Penggunaan bahasa 
Indonesia tersebut pada dasarnya agar semua masyarakat Yogyakarta dapat menerima kehadiran rumah sakit sebagai salah satu pilihan alternatif rumah sakit dalam berobat.

Selanjutnya, penggunaan bahasa Inggris dalam sebuah baliho ditemukan di Yogyakarta. Baliho bertuliskan "wonderful taste of Indonesia" tersebut merupakan baliho sosialisasi kegiatan rutin pemerintah daerah Yogyakarta. Iklan yang menggunakan bahasa Inggris ini memberikan informasi bahwa kegiatan yang disosialisasikan merupakan kegiatan yang bertaraf internasional. Seperti diketahui bahawa bahasa Inggris merupakan bahasa yang digunakan sebagai komunikasi internasional, maka setiap kegiatan yang dirancang berskala internasional juga menggunakan bahasa Inggris sebagai media komunikasinya. Meski aturan pemerintah yang mengharuskan menyandingkan bahasa Indonesia dengan bahasa asing, namun aturan tersebut tidak dijalankan pada iklan sosialisasi ini. Salah satu spanduk rumah makan terpajang di salah satu sudut jalan Wonogiri. Iklan ini pada dasarnya mencoba menarik minat konsumen dengan cara menggunakan nama atau merek dagang yang sudah sangat popular sehingga mencampurkan bahasa asing dan bahasa Indonesia. Spanduk yang bertuliskan "Kenthacky Ayam Crispy" ini bertujuan mengenalkan rumah makan. Namun demikian ${ }_{2}$ penulisan nama sudah sedikit berubah dan disesuaikan dengan penyebutan asli orang Indonesia. Rumah makan ini tergolong rumah makan sederhana. Penggunaan nama rumah makan tidak menandakan bahwa rumah makan tersebut merupakan rumah makan mewah, namun hanya merupakan salah satu strategi dalam menarik minat konsumen. Salah satu yang membuat penggunaan bahasa Inggris sebagai bahasa yang digunakan dalam komunikasi bisnis dikarenakan bahasa Inggris dianggap memiliki nilai jual yang lebih baik dan lebih populer.

Salah satu iklan yang menggunakan bahasa daerah terdapat di daerah Magelang. Iklan yang menggunakan spanduk dan bertuliskan "Tombo Ngelak, Es Degan, Es Dawet" ini meunjukkan salah satu jajanan yang dapat dinikmati oleh semua lapisan masyarakat. Penggunaan bahasa jawa sebagai salah satu penanda bahwa lokasi tempat minum es tersebut berada pada masyarakat yang dominan penduduknya berbahasa Jawa. Selain itu, penggunaan-penggunaan bahasa daerah juga banyak digunakan dalam rangka sebagai penanda bahwa makanan tersebut merupakan makanan khas daerah tertentu, seperti Gudeg yang ada di Yogyakarta, Konro dan Coto yang ada Makassar dan lain sebagainya.

\section{Papan Nama dan Jargon}

Penggunaan papan nama pada suatu instansi atau bangunan sudah lazim ditemukan. Dalam peraturan pemerintah ${ }_{2}$ khususnya mengenai penggunaan bahasa juga telah diatur mengenai penggunaan bahasa Indonesia terhadap nama instansi atau gedung. Salah satu yang marak ditemukan $_{2}$ yaitu penggunaan nama hotel berbintang. Berdasarkan penelusuran peneliti di berbagai tempat terdapat dua pola penggunaan nama hotel. Pola pertama ${ }_{2}$ yaitu menggunakan 
nama hotel sesuai dengan pola urutan kata dalam bahasa Indonesia. Hal ini ditemukan pada hotelhotel seperti "Hotel Perdana" dan "Hotel Kartika". Pola yang kedua ditemukan dengan menggunakan struktur dan nama berbahasa Inggris. Hal ini ditemukan pada penamaan hotel "Grand Tjokro" dan "Indoluxe Hotel". Penggunaan nama hotel juga sesuai dengan kelas hotel tersebut. Untuk dua hotel pertama dengan tarif berbiaya rendah, fasilitas yang ditawarkannya pun tidak semewah hotel berbintang. Sedangkan untuk dua hotel berikutnya sudah menawarkan berbagai fasilitas berskala internasional. Harga yang ditawarkan juga tidak murah, dan biasanya dinikmati oleh kalangan menengah ke atas. Artinya, bahwa penggunaan bahasa pada penamaan hotel tersebut merupakan penanda bagi masyarakat terkait dengan fasilitas dan harga yang ditawarkan oleh hotel.

Penggunaan bahasa yang menarik juga ditemukan pada jargon-jargon yang terpampang di salah satu sudut kampus UNY. Sebelumnya telah dijelaskan bahwa penggunaan bahasa Inggris pada dasarnya dilakukan sebagai penanda ataupun strategi bagi pemilik institusi untuk menandakan bahwa kampus yang dikelolanya siap berkompetisi secara global atau internasional. Jargon-jargon yang dipajang oleh UNY dengan menggunakan bahasa Inggris seperti "Green and Clean University" dan "on the move to World Class University" merupakan bagian dari strategi dan sekaligus penanda bahwa UNY telah bergerak menuju universitas kelas dunia (universitas berskala internasional). Pada jargon tersebut, tidaklah hanya menggunakan bahasa Inggris semata, tetapi tetap menggunakan bahasa Indonesia sebagai padanan dari bahasa Inggris tersebut, meski jika dilihat secara ukuran, bahasa Indonesia yang ditampilkan ukurannya jauh lebih kecil dari bahasa Inggris. Bahasa Inggris yang sudah dikenal sebagai bahasa penghubung dunia internasional digunakan oleh suatu institusi sebagai salah satu strategi dalam mengenalkan kampusnya bahwa kampus tersebut memiliki program-program yang berskala internasional.

\section{Nama Jalan}

Penulisan nama jalan yang disertai dengan aksara bahasa daerah dapat ditemui dibeberapa daerah di Indonesia. Termasuk kota besar seperti Yogyakarta dan Makassar. Penggunaan aksara daerah tentunya telah ditopang oleh kebijakakebijakan pemerintah daerah melalui peraturan gubernur/walikota/ bupati. Hal ini dapat dilakukan bagi bahasa daerah yang memiliki aksara, tetapi tidak sedikit bahasa daerah di Indonesia yang tidak memiliki aksara. Penulisan nama jalan yang diikuti oleh aksara bahasa daerah merupakan salah satu strategi dari pemerintah setempat untuk mempertahankan sekaligus mengenalkan aksara bahasa daerah yang dimiliki oleh bahasa daerah tersebut.

Berdasarkan data penelitian yang dipaparkan sebelumnya, hususnya yang terkait dengan penggunaan bahasa di ranah publik temuan penelitian menunjukkan bahwa penggunaan bahasa di ruang publik cenderung 
disesuaikan dengan kebutuhan pengguna bahasa.Penggunaan atau pemilihan bahasa yang digunakan dipengaruhi oleh tujuan yaitu untuk kebutuhan komersil, dan lebih memilih bahasa yang dapat menampilkan iklan produk dan jasa agar terlihat menarik perhatian. Bahasa yang dipilih untuk mengomunikasikan produk atau jasa yang digunakan biasanya menggunakan bahasa Indonesia dan Inggris, penggunaan bahasa Inggris, dan penggunaan bahasa Indonesia. Pemilihan bahasa yang dimaksud juga dalam raqangka memilah konsumen yang dituju.Penggunaan bahasa Indonesia dan Inggris untuk kalangan terpelajar atau kelas menengah ke atas, dan penggunaan bahasa daerah dikhususkan untuk kalangan daerah tertentu saja.Iklan yang menggunakanbahasa Indonesia dan Inggris juga berlaku secara nasional, sedangkan iklan yang menggunakan bahasa daerah bersifat lokal atau hanya pada daerah tertentu saja.Pola ini tidak hanya berlaku pada iklan, namun juga pada papan nama bangunan komersil seperti hotel.

Penggunaan bahasa di ruang publik juga ditemukan pada instansi pemerintahan dan penggunaan nama jalan.Penggunaan atau pemilihan bahasa pada wilayah ini cenderung disesuaikan dengan kebijakan pemerintah yang tertera pada Undang-Undang No. 28 Tahun 2009.Penggunaan bahasa misalnya yang ditemukan pada institusi negara seperti di Universitas Negeri Yogyakarta (UNY) sudah sesuai dengan aturan yang ditetapkan oleh pemerintah.Penggunaan bahasa Indonesia yang dipadankan dengan bahasa Inggris pada institusi ini dikarenakan kebijakan pimpinjan institusi untuk menggambarkan bahwa institusi yang dipimpinnya memiliki program-program internasional dan menuju universitas yang bersaing di tingkat internasional.

Salah satu penggunaan bahasa yang juga dipengaruhi oleh kebijakan pemerintah daerah setempat yaitu penggunaan bahasa pada papan nama jalan. Pemilihan bahasa pada papan nama jalan juga cenderung disesuaikan dengan aturanpenggunaan bahasa dan kebijakan pemerintah daerah setempat. Beberapa pemerintah daerah yang memiliki aksara lokal cenderung menyandingkankannya dengan bahasa Indonesia dalam penggunaannya khususnya pada nama-nama jalan di daerah tersebut.

\section{PENUTUP}

Berdasarkan hasil penelitian dan kajian kritis peneliti, dapat diperoleh beberapa simpulan sebagai berikut:

1. Kebijakan bahasa dalam rumah tangga dipengaruhi oleh beberapa faktor yaitu bahasa pertama anggota keluarga, bahasa yang digunakan di lingkungan tempat tinggal, dan bahasa pendidikan dan media.

2. Kebijakan pemilihan bahasa di ruang publik dipengaruhi oleh beberapa faktor, yaitu tujuan penggunaan bahasa, kebijakan institusi atau pemerintah daerah, dan aturan penggunaan bahasa yang tertera pada Undang-Undang No. 28 tahun 2009. 
3. Penggunaan bahasa di ranah publik yang umumnya menggunakan campur kode antara bahasa Indonesia dengan bahasa daerah/asing memiliki maksud dan tujuan yang disesuaikan dengan peruntukannya.
4. Penggunaan bahasa asing/Inggrisdi ruang publik masih banyak melanggar peraturan pemerintah yang telah diundangundangkan.

\section{DAFTAR PUSTAKA}

Alwi, Hasan. 2000. Bahasa Indonesia: Pemakai dan Pemakaiannya. Jakarta: Departemen Pendidikan Nasional.

Cooper, Robert L. 1989. Language Planning and Social Change. Cambridge: Cambridge University Press.

Fasold, Ralph. 1984. The Sociolinguistics of Society. Oxford: Basil Blackwell.

Kemendikbud. 2012. Kurikulum 2013. Jakarta: Kementerian Pendidikan dan Kebudayaan.

Lewis, M. Paul. 2009. Ethnologue: Language of the World, Sixteen edition. Dallas, Tex.: SIL International. Online version: http://www.ethnologue.com

Undang-Undang No. 24 Tahun 2009 tentang Bendera, Bahasa dan Lambang Negara, serta Lagu Kebangsaan. 
